\title{
SURFACE TOPOGRAPHY OF THE GREENLAND ICE SHEET BY SATELLITE RADAR ALTIMETRY
}

\section{(Abstract)}

\author{
by
}

R.A. Bindschadler and H.J. Zwally

(NASA, Goddard Space Flight Center, Greenbelt, Maryland, U.S.A.)

\section{ABSTRACT}

A map of the surface elevation for the southern half of the Greenland ice sheet has been produced from data gathered by the radar altimeter on board the SEASAT satellite. From June 1978 until September 1978, useful data were collected during most passes over the ice sheet, but data was not collected continuously along each pass. Over 85000 separate ranges were obtained from the satellite to the surface at points spaced $662 \mathrm{~m}$ apart along each orbital pass.

Techniques required for the reduction of the recorded return waveforms to surface elevations have previously been described in a series of papers (Martin and others, 1983; Brenner and others, 1983; and Zwally and others, 1983). Once all corrections have been applied to the range data due to atmospheric effects, ocean and earth tides, and orbital perturbations, the set of ranges at orbital crossing points (where ascending orbits crossed descending orbits) had a mean relative error of $2.9 \mathrm{~m}$, with a standard deviation of $\pm 2.9 \mathrm{~m}$. Elevations over the flatter and smoother portions of the ice sheet have a precision as small as $\pm 0.25 \mathrm{~m}$, while data over sloping and rough areas are of lower quality. Along each orbital track, the data are corrected for the slope-induced error.

The reduced set of surface elevations has been interpolated to assigned elevation values at the nodal points of a regular grid with a $10 \mathrm{~km}$ spacing (polar stereographic projection). This grid was then contoured at intervals of $50 \mathrm{~m}$ above $2400 \mathrm{~m}$ altitude and $100 \mathrm{~m}$ at lower elevations. Similar grids of slope-induced error corrections were contoured to provide some measure of its effect on the data. Ancillary plots of parameters of the fitting and gridding process are included to help in estimating the quality of the derived surface topography in different regions.
The surface elevation contour map shows the existence of distinct drainage basins within the ice sheet - most notably in the southern and eastern areas. This detail will prove most useful in the delineation of these basins for hydrological or glaciological studies. In combination with ice-thickness data, these elevation data permit a more accurate measurement of the bedrock elevation. The corrected altimeter data in orbital-pass and map format have been provided to the National Space Science Data Center at Goddard Space Flight Center and to the World Data Center-A, Glaciology, as a source of information to be used by other scientific investigators. These data have already been used to produce detailed maps of the topography in more localized areas (e.g. Figure 2, from Zwally and others, 1983 and Figure 2 of Bindschadler, 1984).

\section{REFERENCES}

Bindschadler R A 1984 Jakobshavns glacier drainage basin: a balance assessment. Journal of Geophysical Research 89(C2): 2066-2072

Brenner A C, Bindschadler R A, Thomas R H, Zwally $\mathrm{H}$ 1983 Slope-induced errors in radar altimetry over continental ice sheets. Journal of Geophysical Research 88(C3): 1617-1623

Martin T V, Zwally H J, Brenner A C, Bindschadler R A 1983 Analysis and retracking of continental ice sheet radar altimeter waveforms. Journal of Geophysical Research 88(C3): 1608-1616

Zwally $\mathrm{H} \mathrm{J}$, Bindschadler R A, Brenner A C, Martin T V, Thomas R H 1983 Surface elevation contours of Greenland and Antarctic ice sheets. Journal of Geophysical Research 88(C3): $1589-1596$ 